\title{
ANALISIS WAKTU PEMASAKAN DALAM PROSES PEMBUATAN PERMEN MADU Trigona biroi DAN Apis dorsata
}

\section{(Analysis Of Time In The Making Process Of Making Candy Honeygona biroi and Apis dorsata)}

\author{
Maria', Hadijah Azis K², Muh. Nuh ${ }^{3}$. \\ Program Studi Kehutanan, Fakultas Kehutanan, Universitas Andi Djemma Palopo \\ mariaforestry@gmail.com
}

\begin{abstract}
Honey candy is an innovation in utilizing honey for hygienic consumption, and honey has a high value if it is processed into a candy innovation. This study aims to determine the process of making real honey candy and the ratio of the initial and post-cooking weight of two types of honey, namely Trigona biroi honey and Apis dorsata. The data used in this study are secondary and primary. For one month, data collection took place from September to October 2020 in Waetuo VillageWest Malangke North Luwu. Data were collected from experimental results. This study uses quantitative descriptive analysis presented in tables and paragraph descriptions that provide an overview of the object under study through sample and population data. This study indicates that the weight ratio of Trigona biroi and Apis dorsata honey where the cooking time and honey quality will affect the honey weight. So that in Trigona biroi honey, the water content is higher than that of Apis dorsata. The cooking time for Trigona biroi is 5 minutes to 15 minutes; the final weight is 11 grams, 8 grams, and 5 grams. While the final weight of Apis dorsata is 18 grams, 16 grams, and 14 grams.
\end{abstract}

Keywords: Honey Candy, Temperature, Weight, Trigona biroi, Apis dorsata

\begin{abstract}
ABSTRAK
Permen madu merupakan salah satu inovasi dalam pemanfaatan madu untuk dikonsumsi. Madu memiliki nilai tinggi apabila di proses menjadi sebuah inovasi permen. Penelitian ini bertujuan untuk mengetahui proses pembuatan permen madu asli dan perbandingan berat awal dan setelah pemasakan pada dua jenis madu yaitu madu Trigona biroi dan Apis dorsata. Pengambilan data berlangsung selama 1 bulan yaitu dari bulan September sampai Oktober 2020 di Desa Waetuo Kecamatan Malangke Barat Kabupaten Luwu Utara. Data dikumpulkan dari hasil eksperimen. Penelitian ini menggunakan analisis deskriptif kuantitatif yang disajikan dalam bentuk tabel dan uraian paragrap yang memberikan gambaran terhadap hasil eksperimen pembuatan permen madu. Hasil penelitian ini menunjukkan bahwa perbandingan berat madu Trigona biroi dan Apis dorsata dimana lama pemasakan dan kualitas madu akan mempengaruhi berat madu, sehingga pada madu Trigona biroi didapatkan kandungan air lebih tinggi dibandingkan dengan Apis dorsata. Waktu pemasakan Trigona biroi 5 menit sampai 15 menit di dapatkan berat akhir yaitu 11 gram, 8 gram dan 5 gram. sedangkan Apis dorsata berat akhir yaitu 18 gram, 16 gram dan 14 gram.
\end{abstract}

\section{Kata kunci: Permen Madu, Suhu, Berat, Trigona biroi, Apis dorsata}




\section{PENDAHULUAN}

Lebah madu merupakan salah satu komoditas Hasil Hutan Bukan Kayu (HHBK) yang bernilai ekonomi tinggi dan banyak diusahakan oleh masyarakat di sekitar kawasan hutan. Usaha perlebahan di Indonesia, baik yang dilakukan melalui budidaya maupun non-budidaya mempunyai peluang yang sangat besar untuk dapat dikembangkan menjadi industri perlebahan. Di Sulawesi Selatan, daerah-daerah potensial pengembangan HHBK lebah madu tersebar dibeberapa kabupaten yaitu Kabupaten Bantaeng, Bulukumba, Sinjai, Gowa, Barru, dan Luwu Utara.

Luwu Utara merupakan salah satu wilayah penghasil madu hutan di Provinsi Sulawesi Selatan. Terdapat dua jenis lebah di wilayah ini yaitu Apis dorsata dan Trigona biroi. Lebah hutan (Apis dorsata) merupakan salah satu penghasil madu dengan produksi yang masih terbatas, serta belum dapat dibudidayakan seperti lebah Trigona $s p$. yang saat ini banyak dikembangkan masyarakat di Luwu Utara (Mahmud. 2008).

Lebah madu Trigona biroi masih dibudidayakan secara sederhana dan tradisional mulai dari penggunaan media koloni lebah hingga alat yang digunakan. Perkembangan Trigona biroi merupakan suatu hal yang positif untuk meningkatkan pendapatan kesejahteraan dan pendapatan masyarakat. Pembudidayaan lebah madu Trigona biroi memberikan manfaat secara langsung maupun tidak langsung. Manfaat langsung yang diperoleh yaitu madu dan propolis. Sedangkan manfaat tidak langsung yaitu meningkatkan produksi pertanian, perkebunan, dan kehutanan. Peningkatan kesehatan masyarakat, membuka kesempatan kerja dan usaha, meningkatkan kesejahteraan dan pendapatan masyarakat (Wardoyo. 2016).

Selain lebah Trigona biroi, keberadaan lebah hutan Apis dorsata juga pada saat sekarang ini menjadi lebih diperhatikan oleh masyarakat luas. Hal ini disebabkan semakin meningkatnya kepedulian masyarakat terhadap nilai-nilai kesehatan dan sesuatu yang bernilai organik. Keunggulan pada nilai organik inilah yang menjadikan produk madu hutan dari lebah Apis dorsata lebih menjadi pilihan bagi masyarakat dibandingkan madu ternak Apis mellifera. Hal tersebut disebabkan pada lebah Apis dorsata menghasilkan madu "multiflora" atau madu 3 yang dihasilkan berasal dari berbagai jenis tumbuhan, sehingga bebas dari pestisida dan polusi. Karena tumbuhan yang menjadi sumber makanan Apis dorsata, berasal langsung dari alam liar yang tidak terjangkau oleh pestisida dan polusi. Apis dorsata memiliki ukuran tubuh lebih besar dibanding lebah jenis lainnya. Lebah ini terdapat di hutan daerah sub tropis dan tropis Asia seperti Indonesia, Philipina dan sekitarnya. Penyebarannya di Indonesia merata mulai dari Sumatera sampai Irian (Wardoyo. 2016).

Madu merupakan hasil hutan yang sangat digemari karena manfaatnya sangat beragam. Selain dapat dikonsumsi langsung, madu juga bisa menjadi bahan membuat berbagai jenis makanan.Madu mengandung sumber alami karbohidrat yang memberikan kalori sebanyak $64 \mathrm{kal} /$ sendok makan dan juga mengandung banyak mineral seperti natrium, kalsium, magnesium, aluminium, besi, fosfor dan kalium. Terdapat juga vitamin seperti thiamin (B1), riboplavin (B2), asam askorbat (C), piridoksin (B6), niasin, asam pantoneat, biotin, asam folat dan vitamin K (Adji, 2007).

Selain dikonsumsi secara langsung, madu juga dapat di olah menjadi permen yang mempunyai tekstur yang keras (hard candy). Permen adalah salah satu produk yang digemari baik dari kalangan anak-anak maupun dewasa. Permen sejenis gula-gula yang dibuat dengan mendidihkan campuran madu dan air bersama bahan-bahan lainnya. Madu memiliki banyak khasiat, salah satunya adalah efek antioksidan karena memiliki zat flavonoid (Asari. 2009). 
Hard Candy adalah jenis permen yang mempunyai tekstur keras dan tampak bening serta mengkilap (glossy). Cara mengkonsumsi hard candy dengan soft candy sangat berbeda. Pada hard candy karena mempunyai tekstur yang keras karena bahan yang digunakan maka permen tersebut dikonsumsi dengan cara menghisap, sedangkan soft candy memiliki tekstur yang lunak sehingga dikonsumsi dengan cara dikunyah (Ramadhan. 2012).

Hard candy mengalami pemasakan pada suhu antara $140-150{ }^{\circ} \mathrm{C}$ dan menghasilkan produk dengan penampilan bening. Semakin tinggi suhu yang digunakan untuk pembuatan hard candy maka kekerasannya semakin tinggi dan kadar air semakin rendah. Kristalisasi dalam hard candy akan terjadi secara spontan tetapi dapat dicegah dengan cara penambahan bahan-bahan penghambat kristalisasi, seperti sirup glukosa dan gula invert yang tidak dapat mengkristal. Penggunaan bahan tersebut dalam pembuatan hard candy dapat menghambat terjadinya kristalisasi dan pertumbuhan inti kristal (Anni. 2008).

Pembuatan permen dengan rasa yang sering digunakan adalah jeruk, anggur, apel, jelly dll. saat ini belum terdapat permen berbahan dasar madu asli. Madu mudah ditemukan tetapi belum banyak

\section{Tahap Persiapan}

Menyediakan bahan yang diperlukan dalam penelitian meliputi madu lebah Trigona biroi dan madu lebah Apis dorsata. Sedangkan Alat yang digunakan yaitu kompor, panci, sendok kayu, termometer, stopwatch dan cetakan. Langkah pertama yaitu mengaduk masing-masing madu Trigona biroi dan Apis dorsata memakai sendok kayu.

2. Tahap Pembuatan

Timbang madu dari lebah Trigona biroi dan Apis dorsata masing-masing sebanyak 30 gram, lalu dipanaskan menggunakan panci teflon dengan api yang kecil. Pada saat proses pemanasan sediakan dimanfaatkan seperti dijadikan bahan dasar permen. Berdasarkan uraian diatas, peneliti ingin membuat permen dari madu yang lebih mudah dikonsumsi dan mudah di bawah kapan dan dimana saja. Peneliti bermaksud untuk melaksanakan penelitian dengan judul "Analisis Pengaruh Waktu Pemasakan dalam Proses Pembuatan Permen Madu Trigona biroi dan Apis dorsata".

Tujuan dari penelitian ini adalah untuk mengetahui proses pembuatan permen madu asli dan perbandingan berat awal dan setelah pemasakan pada dua jenis madu yaitu madu Trigona biroi dan Apis dorsata. Lokasi dalam pengambilan madu berada di Desa Waetuo Kecamatan Malangke Barat Kabupaten Luwu Utara

\section{METODE PENELITIAN}

Penelitian ini dilaksanakan di Desa Waetuo, Kecamatan Malangke Barat,

Kabupaten Luwu Utara, Provinsi Sulawesi Selatan pada Bulan September-Oktober Tahun 2020. Bahan yang digunakan adalah lebah madu Trigona biroi dan lebah madu Apis dorsata. Alat yang digunakan pada penelitian ini adalah kompor, panic, sendok kayu, thermometer, stopwatch, timbangan dan cetakan.

stopwatch dan termometer. Perhatikan waktu dan suhu pemasakan madu sampai benarbenar mengental. Selama pemanasan upayakan dilakukan pengadukan secara perlahan agar gelembung udara yang dihasilkan sesedikit mungkin. Penelitian ini menggunakan suhu yang sama yaitu $75^{\circ} \mathrm{C}$ dengan 3 perlakuan menggunakan lama pemasakan yaitu 5 menit, 10 menit dan 15 menit.

3. Tahap Pengemasan

Pencetakan dan pendinginan permen madu Trigona biroi dan Apis dorsata yang telah masak segera dituang ke dalam cetakan berbentuk lingkaran yang telah diolesi dengan minyak permen. Pengolesan dengan 
minyak permen untuk membantu agar permen tidak lengket saat diambil dari cetakan. Setelah itu dilakukan pendinginan.

Teknik analisis data dilakukan dengan menggunakan analisis deskriptif kuantitatif yang disajikan dalam bentuk tabel dan uraian paragraph yang berfungsi untuk mendiskripsikan atau memberikan gambaran terhadap objek yang diteliti melalui data hasil eksperimen pembuatan permen madu Trigona biroi dan Apis dorsata.

Penelitian ini menggunakan penelitian eksperimen dengan prosedur sebagai berikut:

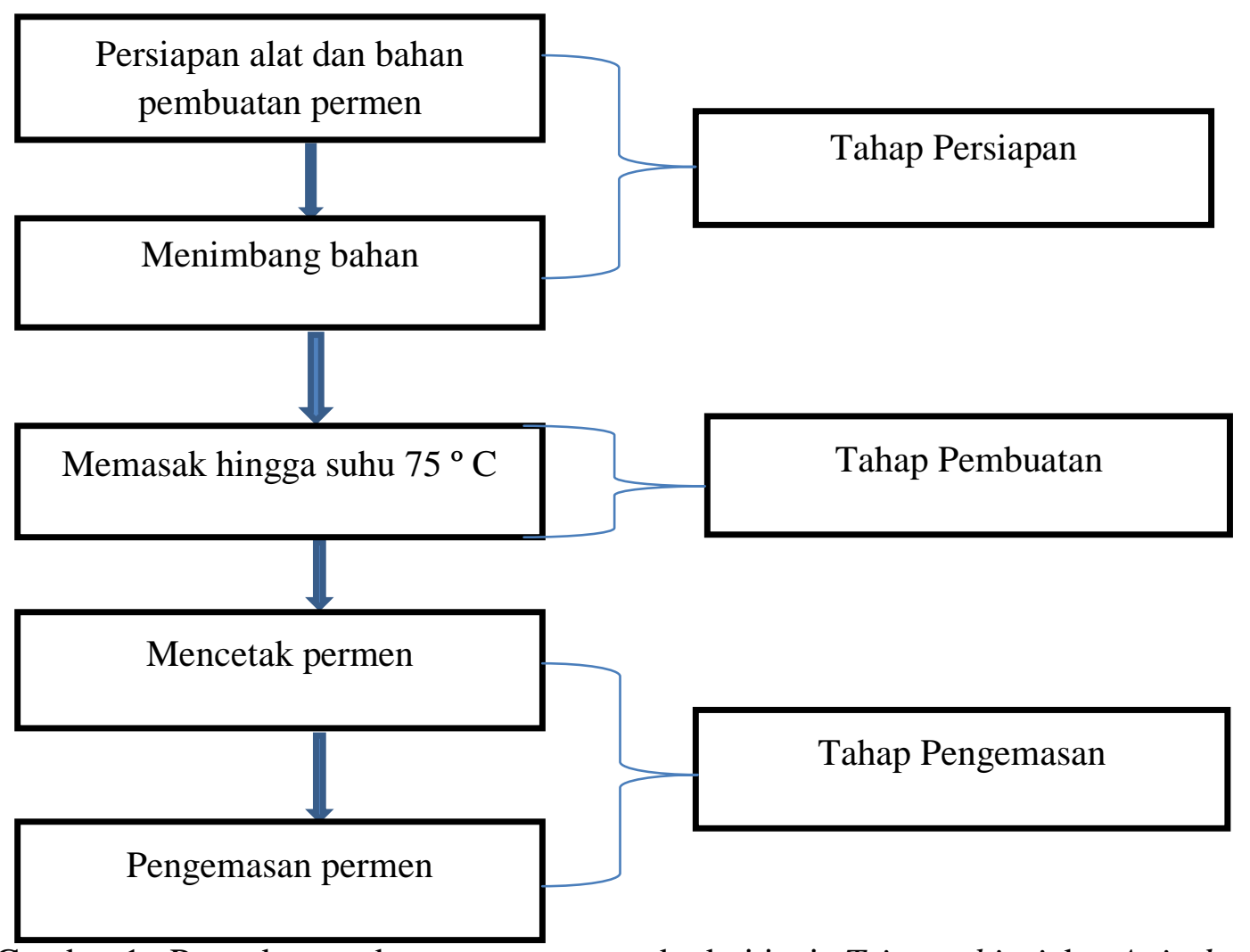

Gambar 1. Prosedur pembuatan permen madu dari jenis Trigona biroi dan Apis dorsata

\section{HASIL DAN PEMBAHASAN}

\section{A. Perbandingan Berat Awal dan Akhir Permen Madu Trigona biroi sebelum dan sesudah pemasakan}

Berdasarkan eksperimen yang telah dilakukan, hasil perbandingan berat dan kandungan permen madu Trigona biroi sebelum dan sesudah pemasakan dapat dilihat pada tabel berikut :

Tabel 1. Hasil perbandingan berat awal dan berat akhit permen Trigona biroi

\begin{tabular}{|c|c|c|c|c|c|c|c|c|}
\hline \multirow{2}{*}{$\begin{array}{l}\text { Suhu } \\
\left({ }^{\circ} \mathrm{C}\right)\end{array}$} & \multirow{2}{*}{$\begin{array}{c}\text { Waktu } \\
\text { Pemasakan } \\
\text { (Menit) }\end{array}$} & \multirow{2}{*}{$\begin{array}{c}\text { Berat } \\
\text { Awal } \\
\text { (Gram) }\end{array}$} & \multicolumn{3}{|c|}{$\begin{array}{l}\text { Berat Akhir } \\
\text { (Gram) }\end{array}$} & \multirow{2}{*}{$\begin{array}{c}\text { Waktu } \\
\text { Pengerasan } \\
\text { (Menit) }\end{array}$} & \multirow[t]{2}{*}{ Tekstur } & \multirow{2}{*}{$\begin{array}{c}\text { Berat } \\
\text { Hilang } \\
\quad(\%)\end{array}$} \\
\hline & & & U1 & $\mathrm{U} 2$ & U3 & & & \\
\hline \multirow[t]{2}{*}{75} & \multirow[t]{2}{*}{5} & \multirow[t]{2}{*}{30} & 11 & 11 & 11 & \multirow[t]{2}{*}{60} & \multirow[t]{2}{*}{ Kenyal } & \multirow[t]{2}{*}{63,33} \\
\hline & & & 8 & 8 & 8 & & & \\
\hline
\end{tabular}


Volume 3 Nomor 1 Juli 2021:45-54

\begin{tabular}{lllllllll}
75 & 10 & 30 & 8 & 8 & 8 & 35 & Keras & 73,33 \\
& & & 8 & 8 & 8 & & & \\
75 & 15 & 3 & 3 & 3 & & & \\
& & 3 & 3 & 3 & 3 & 10 & Keras & 83,33 \\
\hline
\end{tabular}

Sumber : Data primer setelah diolah, 2021

Berdasarkan hasil uji coba pertama permen madu Trigona biroi dilakukan sebanyak 3 kali percobaan, setiap percobaan dilakukan 3 kali ulangan pada suhu $75^{\circ} \mathrm{C}$ dengan waktu 5 menit. Berat madu sebelum pemasakan 30 gram, berat madu yang dihasilkan dari pemanasan dengan 9 kali ulangan yaitu 11 gram. Waktu yang dibutuhkan permen madu Trigona biroi untuk mengeras selama 60 menit, sehingga rata-rata berat yang hilang yaitu $63.33 \%$.

Percobaan kedua dilakukan sebanyak 3 kali percobaan, setiap percobaan dilakukan dengan 3 kali ulangan pada suhu $75^{\circ} \mathrm{C}$ dengan waktu 10 menit. Berat awal 30 gram dan setelah pemasakan dengan 9 kali ulangan mendapatkan hasil yang sama yaitu 8 gram. Waktu yang dibutuhkan permen madu Trigona biroi untuk mengeras pada percobaan ini yaitu 35 menit. Berat madu yang awalnya 30 gram menjadi 8 gram dengan tekstur mengeras rata-rata berat yang hilang yaitu $73.33 \%$.

Percobaan ketiga dilakukan dilakukan sebanyak 3 kali percobaan, setiap percobaan dilakukan 3 kali ulangan pada suhu 75 dengan waktu 15 menit. Berat awal 30 gram, perubahan berat madu yang dihasilkan setelah pemasakan dari 9 kali ulangan mendapatkan hasil yang sama yaitu 5 gram. Waktu yang dibutuhkan permen madu Trigona biroi untuk mengeras yaitu 10 menit. Berat madu yang awalnya 30 gram menjadi 5 gram dengan tekstur mengeras rata-rata berat yang hilang $83,33 \%$.

Percobaan pembuatan permen madu Trigona biroi pada table 1 yang dilakukan dengan waktu pemasakan 5 menit, 10 menit dan 15 menit masing-masing dilakukan 9 kali percobaan di dapatkan rata-rata berat akhir pada waktu 5 menit yaitu 11 gram. 10 menit 8 gram dan 15 menit 5 gram. Hal ini menunjukkan bahwa semakin lama waktu pemasakan, maka semakin banyak kandungan air yang hilang pada madu tersebut karena adanya proses pemanasan. Proses pemasakan dilakukan untuk meningkatkan visikositas produk madu dan mempercepat penguapan air dalam madu. Menurut Fitriani (2008), bahwa semakin lama waktu pemasakan, kadar air akan menurun, menyebabkan penguapan air lebih banyak sehingga kadar air dalam bahan semakin kecil. Penguapan tersebut juga diakibatkan karena terjadinya perbedaan tekanan uap antara air pada bahan dengan uap air pada udara. Tekanan tiap air pada bahan umumnya lebih besar dari tekanan uap air di udara sehingga terjadi perpindahan massa air dari bahan ke udara.

Madu Trigona biroi sebelum pemanasan memiliki rasa asam sangat tinggi karena kandungan air yang banyak sehingga hasil dari uji coba permen madu Trigona biroi mempengaruhi warna, rasa, tesktur dan kualitas permen. Pada pemanasan 5 menit didapatkan tekstur kenyal dimana proses pemasakan belum seutuhnya mengental lalu diangkat dengan rasa asam. Warna pada madu Trigona biroi pada dasarnya gelap berwarna cokelat tua sehingga hasil yang didapatkan setelah pemanasan aroma bau dan warna akan semakin gelap. Uji coba yang dilakukan pada waktu pemasakan 15 menit tekstur yang dihasilkan keras karena kandungan air yang terdapat pada madu tersebut semakin berkurang pada proses pemanasan, waktu yang dibutuhkan untuk mengeras yaitu hanya 10 menit, semakin lama waktu yang digunakan dalam proses 
pemasakan maka semakin sedikit waktu yang dibutuhkan dalam proses pengerasan.

Kadar air pada madu berpengaruh terhadap kualitas madu. Hal ini disebabkan karena madu yang baik dapat dilihat dari kualitas kadar madu tersebut. Persyaratan kadar air pada madu berdasarkan SNI 013545-2013 adalah maksimal $22 \%$. antara $14 \%$ hingga $18 \%$. tinggi rendahnya kadar air pada madu dapat dipengaruhi oleh beberapa faktor yakni suhu. Proses pemanenan dan jenis nektar di sekitar lebah. Kadar air madu juga dipengaruhi oleh lama penyimpanan pada madu. (Saragi, dkk,1981). Suhu lingkungan juga menjadi salah satu factor yang berpengaruh terhadap kadar air, semakin tinggi suatu daerah maka suhu akan semakin menurun. Hal ini disebabkan adanya perbedaan geografis terhadap ketinggian tempat diatas permukaan laut. (Adriani. 2013).

Keasaman yang tinggi dapat dipengaruhi oleh kadar air dalam madu. tingginya kadar air dan keasaman suatu madu akan menyebabkan proses fermentasi pada madu menjadi semakin asam dan tingkat keasaman dipengaruhi oleh $\mathrm{pH}$ pada madu. (Savitri. 2017). Terjadinya keasaman pada madu dapat dipengaruhi oleh sumber nektar, tempat budidaya, dan waktu panen. (Carvalho et al, 2009). Warna pada madu bergantung pada jenis tanaman serta sifat tanahnya. Namun warna pada madu juga dipengaruhi oleh tingkat pemanasanya. Semakin lama pemanasan maka warna akan semakin tua. Selain itu pemanasan juga akan membentuk kerak gula berwarna coklat dan akan memberikan bau gosong pada madu. Aroma pada madu juga berkaitan dengan warna madu. Aroma pada madu akaan semakin tajam ketika warnanya semakin gelap. Namun aroma pada madu bersifat volatil. Pemanasan dapat menyebabkan sebagian aroma menghilang dan akan menghilang pada proses ekstraksi. Oleh karena itu sebaiknya pemanasan madu terlalu lama harus dihindari untuk menjaga aroma pada madu. (Adriani. 2013).

\section{B. Perbandingan Berat Awal dan Berat Akhir Permen Madu Apis dorsata sebelum dan sesudah pemasakan}

Dari hasil eksperimen pengelolaan madu Apis dorsata menjadi permen madu, diperoleh hasil berat akhir permen madu Apis dorsata sebagai berikut:

Tabel 2. Perbandingan berat awal dan akhir permen madu Apis dorsata

\begin{tabular}{|c|c|c|c|c|c|c|c|c|}
\hline \multirow{2}{*}{$\begin{array}{l}\text { Suhu } \\
\left({ }^{\circ} \mathrm{C}\right)\end{array}$} & \multirow{2}{*}{$\begin{array}{c}\text { Waktu } \\
\text { Pemasakan } \\
\text { (Menit) }\end{array}$} & \multirow{2}{*}{$\begin{array}{c}\text { Berat } \\
\text { Awal } \\
\text { (Gram) }\end{array}$} & \multicolumn{3}{|c|}{$\begin{array}{l}\text { Berat Akhir } \\
\text { (Gram) }\end{array}$} & \multirow{2}{*}{$\begin{array}{c}\text { Waktu } \\
\text { Pengerasan } \\
\text { (Menit) }\end{array}$} & \multirow[t]{2}{*}{ Tekstur } & \multirow{2}{*}{$\begin{array}{c}\text { Berat } \\
\text { Hilang } \\
(\%)\end{array}$} \\
\hline & & & U1 & $\mathbf{U} 2$ & $\mathbf{U 3}$ & & & \\
\hline \multirow{3}{*}{75} & \multirow{3}{*}{5} & \multirow{3}{*}{30} & 18 & 18 & 18 & \multirow{3}{*}{60} & \multirow{3}{*}{ Kenyal } & \multirow{3}{*}{40,00} \\
\hline & & & 18 & 18 & 18 & & & \\
\hline & & & 18 & 18 & 18 & & & \\
\hline & \multirow{4}{*}{10} & \multirow{4}{*}{30} & 16 & 16 & 16 & \multirow{3}{*}{35} & & \multirow{3}{*}{46,67} \\
\hline \multirow[t]{3}{*}{75} & & & 16 & 16 & 16 & & \multirow[t]{2}{*}{ Keras } & \\
\hline & & & 16 & 16 & 16 & & & \\
\hline & & & 14 & 14 & 14 & \multirow{3}{*}{10} & \multirow{3}{*}{ Keras } & \multirow{3}{*}{53,33} \\
\hline \multirow[t]{2}{*}{75} & \multirow[t]{2}{*}{15} & \multirow[t]{2}{*}{30} & 14 & 14 & 14 & & & \\
\hline & & & 14 & 14 & 14 & & & \\
\hline
\end{tabular}

Sumber : Data primer setelah diolah, 2021

Percobaan pertama dilakukan sebanyak 3 kali masing-masing 3 ulangan pada suhu $75^{\circ} \mathrm{C}$ dengan waktu 5 menit. Berat awal madu sebelum pemasakan 30 gram dan 
setelah dipanaskan melalui proses pemasakan mendapatkan hasil yang sama yaitu 18 gram. Waktu yang dibutuhkan permen madu Apis dorsata untuk mengeras selama 60 menit berat madu yang awalnya 30 gram menjadi 18 gram. Pada berat akhir dengan tekstur permen mengenyal rata-rata berat yang hilang yaitu $40.00 \%$.

Percobaan kedua dilakukan sebanyak 3 kali masing-masing 3 ulangan pada suhu $75^{\circ} \mathrm{C}$ dengan waktu 10 menit. Berat awal 30 gram, perubahan berat madu yang dihasilkan dari pemanasan setelah pemasakan mendapatkan hasil yang sama yaitu 16 gram. Waktu yang dibutuhkan permen madu Apis dorsata untuk mengeras yaitu 35 menit. Berat madu yang awalnya 30 gram menjadi 16 gram dengan tekstur mengeras rata-rata berat yang hilang yaitu $46,67 \%$.

Percobaan ketiga dilakukan sebanyak 9 kali pada suhu 75 dengan waktu 15 menit dengan berat awal 30 gram perubahan berat madu yang dihasilkan dari pemanasan dengan 9 kali percobaan mendapatkan hasil yang sama yaitu 14 gram. Waktu yang dibutuhkan permen madu Apis dorsata untuk mengeras yaitu 15 menit. Berat madu yang awalnya 30 gram menjadi 14 gram dengan tekstur mengeras rata-rata berat yang hilang yaitu $53,33 \%$. Dari 3 eksperimen yang dilakukan maka semakin lama waktu yang digunakan dalam proses pemasakan maka semakin sedikit waktu yang dibutuhkan dalam proses pengerasan.

\section{Perbandingan Berat Awal dan Akhir Permen Madu Trigona biroi dan Apis dorsata}

Perbandingan berat awal dan akhir permen Trigona biroi dan Apis dorsata dapat dilihat pada table berikut :

Tabel 3. Perbandingan berat awal dan akhir permen madu Trigona biroi dan Apis dorsata

\begin{tabular}{ccccccc}
\hline \multirow{2}{*}{$\begin{array}{c}\text { Suhu } \\
\left({ }^{\circ} \mathrm{C}\right)\end{array}$} & $\begin{array}{c}\text { Waktu } \\
\text { Pemasakan } \\
(\text { Menit })\end{array}$ & $\begin{array}{c}\text { Berat } \\
\text { Awal } \\
(\text { Gram })\end{array}$ & $\begin{array}{c}\text { Trigona biroi } \\
\text { Berat } \\
(\text { Gram })\end{array}$ & $\begin{array}{c}\text { Berat } \\
\text { Hilang } \\
(\%)\end{array}$ & $\begin{array}{c}\text { Berat } \\
\text { Akhir } \\
(\text { Gram })\end{array}$ & $\begin{array}{c}\text { Berat } \\
\text { Hilang } \\
(\%)\end{array}$ \\
\hline 75 & 5 & 30 & 11 & 63,33 & 18 & 40,00 \\
75 & 10 & 30 & 8 & 73,33 & 16 & 46,67 \\
75 & 15 & 30 & 5 & 83,33 & 14 & 53,33 \\
\hline
\end{tabular}

Sumber : Data primer setelah diolah,2021

Berdasarkan table 3, menunjukkan bahwa madu Trigona biroi dan Apis dorsata semakin lama waktu pemanasan maka berat madu akan semakin menurun. Namun pada madu Trigona biroi sangat terlihat jelas bahwa kandungan air pada madu tersebut sangat tinggi sehingga pada pemanasan waktu 15 menit di hasilkan hasil akhir 5 gram sedangkan pada Apis dorsata di waktu 15 menit mendapatkan berat akhir 14 gram. Waktu pemasakan 5-15 menit berat akhir yang di dapatkan dari madu dan Apis dorsata berbeda jauh karena pada Trigona biroi lebih banyak mengandung kadar air dibandingkan dengan Apis dorsata. Semakin lama pemanasan melalui proses pemasakan berat madu akan terus berkurang, tekstur pada madu Trigona biroi dan Apis dorsata pada waktu 5 menit yaitu kenyal dan waktu 10-15 menit teksturnya sama-sama keras.

Kandungan senyawa kimia pada madu Trigona biroi memiliki spesifik yaitu memiliki $\mathrm{pH} \mathrm{4,} \mathrm{warna} \mathrm{coklat} \mathrm{tua} \mathrm{dan} \mathrm{encer,}$ kadar air sampai dengan $23,4 \%$, gula reduksi $44,7 \%$ serta didominasi oleh senyawa Heptadecene 8\% Carbonic Acid yang tergolong senyawa fenol. Jumlah mikrobia yang ditemukan pada madu 6,2 $103 \mathrm{CFU/}$ mL.Madu Trigona biroi mampu menghambat pertumbuhan bakteri (Staphylococcus 
Aureus dan Pseudomonas Aureginosa). Indeks penghambatan madu terhadap Staphylococcus Aureus adalah 1,11\% Pseudomonas Aeruginosa adalah 2,66\% dan Candida Albican adalah $1,71 \%$. Daya antimikrobia madu Trigona biroi disebabkan adanya senyawa kimia yang berasal dari asam lemak, Flavonoid, dan fenol serta dari Isolate mikrobia yang memiliki kemampuan untuk menghambat pertumbuhan mikrobia pathogen. ( Yuliana Renita. et all. 2015).

Kandungan senyawa fenolik

(Phenolic Acid, Flavonoid dan Tanin) yang terdapat dalam sarang lebah madu Trigona biroi juga dapat menghambat pertumbuhan bakteri gram positif seperti Staphylococcus dan Enterococcus juga bakteri gram negatif seperti Escherichia Coli dan Proteus Mirabilis (Alves et all. 2013). Kadar fenol dalam sarang lebah madu Trigona biroi yaitu kantong polen pada sarang madu $0 \%$, kantong madu $0,22 \%$, kantong telur $0,87 \%$, dan penutup sarang $0,27 \%$ kadar fenol tertinggi terdapat pada kantong telur.( Nitiema et all. 2012).

Perbedaan komposisi madu dapat di sebabkan oleh perbedaan iklim. Iklim merupakan faktor salah satu bagian penting untuk perkembangan lebah yaitu dengan suhu 26 pada suhu ini lebah dapat beraktivitas normal. Lokasi yang baik untuk lebah merupakan tempat terbuka jauh dari keramaian dan banyak terdapat bunga sebagai pakannya( Rosidah. 2016).

\begin{tabular}{ccc} 
Tabel 4. Komposisi Lebah Madu Trigona biroi dan Apis dorsata \\
\hline Komposisi Madu & $\begin{array}{c}\text { Trigona } \\
\text { biroi }\end{array}$ & $\begin{array}{c}\text { Apis } \\
\text { dorsata }\end{array}$ \\
\hline Kadar air (\%) & 23,4 & 19,2 \\
Keasaman (meq/kg) & 48,55 & 6,73 \\
Ph & 4,0 & 4,0 \\
Warna & Coklat & Coklat \\
Tat Aktif & Tua & Muda \\
(Fitokimia) & 5,0 & 5,2 \\
Glukosa(\%) & $8,20-30,98$ & 27,11 \\
Fruktosa(\%) & 40,20 & 40,73 \\
Sukrosa (\%) & 0,31 & 0,61 \\
Gula (Karbohidrat) & 44,7 & 68,45 \\
(\%) & &
\end{tabular}

(Sumber: Adalina, 2017).

Komponen terbesar madu terdiri dari karbohidrat (gula sederhana) dan air. Mutu madu di Indonesia diatur dalam Standar Nasional Indonesia (SNI) Nomor 01-35452013. Madu yang baik harus dapat memenuhi ketentuan yang ditetapkan oleh standar nasional Indonesia (SNI) 2013.
Standar mutu madu yang yang berlaku di Indonesia yang ditetapkan oleh badan standarisasi Nasional (BSN) sebagai acuan sehingga madu madu yang beredar di pasaran dapat terjamin mutu dan keamanannya. 
Tabel 5. Persyaratan Mutu Madu BSN 3545:2013

\begin{tabular}{cccc}
\hline No & Jenis Uji & Satuan & Persyaratan \\
\hline 1 & Bau & & Khas madu \\
2 & Rasa & & Khas madu \\
3 & Warna & & Khas madu \\
4 & Kekentalan & Khas madu \\
5 & Ph & $\% \mathrm{~b} / \mathrm{b}$ & Maks 0,5 \\
6 & Abu & $\% \mathrm{~b} / \mathrm{b}$ & Maks 22 \\
7 & Kadar Air & $\% \mathrm{~b} / \mathrm{b}$ & Min 65 \\
8 & Gula Pereduksi & $\% \mathrm{~b} / \mathrm{b}$ & Maks 5 \\
9 & Karbohidrat) & $\mathrm{Ml}$ & Maks 50 \\
10 & Sukrosa & $\mathrm{NaOH} / \mathrm{kg}$ & \\
& Keasaman & $\% \mathrm{~b} / \mathrm{b}$ & Maks 0,5 \\
\hline
\end{tabular}

(Sumber: BSN Badan Standar Nasional 3545-2013).

\section{KESIMPULAN}

Berdasarkan hasil yang diperoleh bahwa perbandingan berat madu Trigona biroi dan Apis dorsata dan sesudah proses pemasakan dengan berat awal yang sama 30 gram dipengaruhi oleh waktu pemasakan dan kadar air. Madu Trigona biroi di dapatkan kandungan air lebih tinggi dibandingkan dengan Apis dorsata, sehingga berat yang hilang pada madu Apis dorsata labih sedikit dibandingkan madu Trigona biroi. Berat akhir permen madu Trigona biroi pada waktu pemasakan 5 menit, 10 menit dan 15 menit yaitu 11 gram, 8 gram, dan 5 gram. Berat akhir permen madu Apis dorsata pada waktu pemasakan 5 menit, 10 menit dan 15 menit yaitu 18 gram,16 gram, dan 14 gram.

\section{DAFTAR PUSTAKA}

Adalina, Y. 2017. Kualitas Madu Putih Asal Provinsi Nusa Tenggara Barat. Jurnal Prosding Nasional Masyarakat Biodiversitas Indonesia. (3) 2:189193.
Adji Suranto. 2007. Terapi Madu. Jakarta: Penebar Swadaya.

Adriani Rizky. 2013. Identifikasi dan Karakterisasi Sifat Kimia dan Sifat Fisika dari Madu Asli dengan Madu dang Dijual di Pasaran Medan. Skripsi. Fakultas Matematika Dan Ilmu Pengetahuan Alam Universitas Sumatera Utara.

Anni. 2008. Patiseri. Direktorat Pembinaan Sekolah Menengah Kejuruan: Jakarta Alves M., Fereeira I., Froufe H., Abreu R., Martins A dan Pintado M. 2013. Antimicrobial Activity Of Phenolic Compound Identified In Wild Mushrooms, SAR Analysis And Docking Studies. Journal of applied microbiology ISSN 1364-5072. di akses tanggal 10 Desembe r 2020.

Carvalho C A L, dkk.2009. Physicochemical Characteristic and Sensory Profile of Honey Samples From Stringless Bees (Apidae: Meliponinae) Submitted to ad Dehumidification Process. An Acad Bras Clenc 81, No 1: h.143149. 
Mahmud, A, 2008. Pengembangan Lebah Madu dalam Rangka Gerakan

Pembangunan Masyarakat di Provinsi Sulawesi Selatan. Jurnal Hutan dan Masyarakat Vol. III. 1 Mei 2008, 001-110. Dinas Kehutanan Provinsi Sulawesi Selatan: Makasaar

Nitiema L., Savadogo A., Simpore J., Dianou D., dan Traore A. 2012. In Vitro Antimicrobial Activity Some Phenolic Compounds (Coumarin And Quercetin) against gastroenteritis bacteria strains. International Journal of Microbiological Research 3(3): 183-187.

Ramadhan. 2012. Pembuatan Permen Hard Candy yang Mengandung Propolis. Universitas Sumatera Utara: Sumut.

Savitri. 2017. Kualitas Madu Lokal dari Beberapa Wilayah di Kabupaten
Temanggung. Jurnal Undip 2, No 1: h. 58-66.

Sugiono. 2012. Metode Penelitian Kuantitatif Kualitatif dan $R \& D$. Alfabeta: Bandung.

Yuliana R., Endang s., Harry B S., Krisno A H., dan Septiantina D R. 2015. Daya Antimikrobia Sarang Lebah Madu Trigona biroiTerhadap Mikrobia Patogen. Journal Bioedukasi ISSN: 1693-2654, Vol 8. No 1 Hal 677-72. Diakses tanggal 10 Desember 2020.

Wardoyo M R, Lamusa A, Afandi. 2016. Analisis kekayaan usaha ternak lebah madu jaya makmur di desa jono oge kecamatan sigi biromaru kabupaten sigi. Agrotekbis 4 (1): 84-90. http://jurnal . untad ac.id/jurnal/index.php/agrotekbis/arti cle/view/5590. (20 Maret 2020). 